\title{
IMPACT OF BROKEN HOMES ON MATHEMATICS STUDENTS ACADEMIC ACHIEVEMENT IN SENIOR SECONDARY SCHOOLS IN NASSARAWA ZONAL EDUCATION AREA, KANO STATE - NIGERIA
}

\author{
DR. ISA, SURAJO GAYA \\ DEPARTMENT OF COMPUTING AND MATHEMATICS EDUCATION, \\ KANO UNIVERSITY OF SCIENCE AND TECHNOLOGY, WUDIL KANO STATE - NIGERIA \\ DOI: $10.31364 / \mathrm{SCIRJ} / \mathrm{V} 7.110 .2019 . P 1019708$ \\ http://dx.doi.org/10.31364/SCIRJ/v7.i10.2019.P1019708
}

\begin{abstract}
This study was carried out to determine the impact of broken homes on mathematics students' academic achievement in senior secondary schools in nassarawa zonal education area, kano state. A sample of 349 out of a population of 21,403 students from 24 schools was randomly drawn. A survey research design was used. A researcher constructed questionnaire was used after being validated and subjected to a pilot trial. A reliability cofficient of $r=0.86$ was obtained while two psychology and one English language specialists validated the questionnaire. In addition to the questionnaire, the students' 2 nd year third term senior secondary school examination mathematics results were used. Three hypotheses treating whether or not a significant difference exist between students from stable and broken homes, male and female students from broken homes as well as students from broken high and low income were formulated. The t-test analysis showed students from stable homes perform significantly better than those from broken homes with no significant difference in achievement between male and female students from broken home but there is a significant difference in academic achievement between students from high and low home. It was recommended that teaching of family ethics should be emphasized in schools.
\end{abstract}

Keywords: Broken Homes, Academic Performance, Gender, Socio Economic Status

\section{Background}

Science undoubtedly takes care of our physiological and physical needs. Indeed, without science there will be no electricity, among many other human needs, which makes life enjoyable and meaningful. In as much as science makes life easier, there will be no science without mathematics. Dorle (2015) believed that there will be no physics and chemistry without calculus and electronics as well as complex numbers.

Though mathematics is the pillar upon which national technological development rest, but students who sit for public examinations like the West African Examinations Council (WAEC) and National Examinations Council (NECO) record mass failure. Isa (2010) reported that Kano State students' mathematics performance in public examinations continues to deteriorate over the years. He argued that, in 2002 only $24.4 \%$ and $18.6 \%$ of kano state students who sat for the West African Examinations Council(WAEC) and the National Examinations Council(NECO) had a pass and above in the subject respectively. Similarly, in 2003 only $35.9 \%$ and $17.1 \%$ of the students had a pass and above in mathematics respectively. Many factors are responsible for this mass failure. These include students' home background (Alika \& Edosa, 2012) as well as (Zubairu et al., 2018). The home is vital to the child's growth and possibly his/her future. Therefore, the better the home the more likely the child will grow with positive attitudes. By convention, a home is ether intact/stable or broken(Alika\&Edosa,2012).A stable home is the one where the mother and father live together while a broken home is the one where at least one or none of the parents are living together with the children. 
The basic and perhaps the important unit of a society is the family. A home is where the family resides. Thus, the home has a lot to offer in the life of the child. To some people the home is the first learning environment (informal school) of the child. Thus, how intact or broken a home is will be important to the development of the child.

A broken home comes about when a family is engulfed with misunderstanding of marriage. A dictionary meaning of a home is a family unit which consists of the father, mother, and children and in some cases members of the extended family. Broken home is a term used when either the father or mother is no longer part of the family. Reasons for broken homes include:- separation, divorce, death or interfamily misunderstanding.

Some common causes of broken homes include, but not limited, lack of effective communication, abuse and bad or external influences. Resultant effects of broken home on children include loose of interest in life, negative effect on children's performance as well as emotional instability.

The family plays an important role on the academic achievement of the child (Datta, 2014). Couples who are happy in their roles effectively and happily are more likely to have their children performed better in schools (Datta, 2014). Conversely, children from broken homes are less likely to perform very well in schools. Educators forwarded many suggestions on the factors that might affect students' mathematics achievement. These factors include students' background peer environment and parental involvement [Young, Reynolds \& Walberg, (1996)] and (Muller, Stage \& Kinzie 2001).

Datta (2014) asserted that the relationship within the family is likely to influence child's mental health and the personality traits which are in turn closely related to the child's academic performance.

Parental socio - economic status and academic performance has received the attention of many educators. Ogunshola and Adewale (2012) quoted Rothestein (2004) as follows:-"Parents of different occupation classes often have different styles of child rearing, different ways to discipline their children and different ways of reacting to their children." Thus the socio - economic status could affect the academic performance of the child among other factors.

\section{Statement of the Problem}

It is common to see children subjected to partial or total lack of care due to the absence of one or both parents. Such children suffer from diseases, lack or poor place to live in, lack of food to eat etc .In short such children have little or lack of care, security and support. These and other problems affect the children in school in particular and in life generally.

In essence it becomes imperative to investigate the impact of broken homes on mathematics students' academic achievement in senior secondary schools in kano state, Nigeria. This guided the study.

\section{Objectives of the Study}

The following are objectives of the study:-

1.To determine the difference in mathematics academic achievement between Senior Secondary Schools students from stable and broken homes.

2.To determine the gender differences in impact of broken homes in mathematics academic performance among senior secondary schools in Nassarawa Zonal Education Area who suffered most between boys and girls when homes are broken. 
3.To determine the influence of S.E.S. on mathematics achievement of senior secondary schools students in Nassarawa Zonal Education Area.

\section{HYPOTHESES}

The following hypotheses were generated to guide this study:

1.There is no significant difference in the mean score of students' mathematics academic performance between those from stable and broken homes in Nassarawa Zonal Education Area.

2.There is no significant difference in the mean score of students' mathematics academic performance between male and female students from broken homes.

3. Parental S.E.S. does not significantly influence students' academic performance in mathematics among senior secondary school students in Nassarawa Zonal Education Area.

\section{METHODOLOGY}

\section{Research Design}

Survey design is used in this study. Ipaye (2016) described descriptive survey as a useful tool especially when no attempt is required to manipulate variables and phenomena is being described as they are.

\section{Population}

The population consisted of all the 21,403 students in 24 schools in Nasarawa Zonal Education Office as at December, 2014.

\section{Sample}

The sample is made of 349 students randomly selected from the population.

\section{Sampling Technique}

The study used cluster sampling technique. Maiwada and Yakasai (2015) viewed cluster as "naturally occurring groups of subjects". Using the technique the researchers picked a few clusters (schools) and then collected data from the subjects (students).

\section{Instrumentation}

Researcher made questionnaire was used to collect data for the study.

\section{Validity and reliability of the instrument}

The questionnaire was validated by two psychology experts as well as an English Language specialist. Thus, the instrument was subjected to face and content validation.

To compute the reliability of the instrument, a pilot trial was carried out in a different school (not included in the main study) within the same education zone. From the results of the pilot trial a reliability coefficient of $r=0.86$ was obtained. 


\section{Data analysis technique.}

A t-test for independent sample was used to analyse the data obtained.

\section{Data presentation}

Ho $_{\mathrm{i}}$ : There is no significant difference between students' mathematics academic performance on stable \&broken homes.

Table $1 \mathrm{t}$-test for difference in mathematics performance between students from stable and broken homes

\begin{tabular}{|l|l|l|l|l|l|l|l|}
\hline Group & N & X & SD & Df & t & P & Decision \\
Stable & 251 & 5.34 & 7.04 & 347 & 5.44 & 1.65 & Significant \\
Broken Homes & 98 & 3.71 & 5.96 & & & & \\
& & & & & & & \\
\hline
\end{tabular}

$\mathrm{P} \leq 0.05$

Results from 1 showed that $\mathrm{t}$-calculated $>\mathrm{p}$-value with $\mathrm{df}=347$ at $\mathrm{P} \leq 0.05$ level of significance. That is to say the null hypothesis is rejected. Thus, students from stable homes performed significantly better than those from broken homes.

$\mathbf{H o}_{2}$ : Parental socio - economic status does not significantly influence students' academic performance in mathematics.

Table 2 t-test for difference in performance analysis on broken homes with hi gh and low income.

\begin{tabular}{|l|l|l|l|l|l|l|l|}
\hline Group & N & X & SD & Df & t & p & Decision \\
\hline Broken High Income & 44 & 4.55 & 6.58 & 96 & 3.18 & 1.66 & Significant \\
\hline Broken Low Income & & & & & & & \\
& & 54 & 3.04 & 4.53 & & & \\
\hline
\end{tabular}

$\mathrm{P} \leq 0.05$

From the results it is obvious that there is a significant difference in academic performance of students from high income broke homes and those from the low income broken homes.

$\mathrm{Ho}_{3}$ : There is no significant difference in academic performance between male and female students from broken homes.

Table 3 t-test for difference in performance analysis on broken home between male and female students.

\begin{tabular}{|c|c|c|c|c|c|c|c|}
\hline Group & $\mathrm{N}$ & $\mathrm{X}$ & $\mathrm{SD}$ & Df & $\mathrm{t}$ & $\mathrm{p}$ & Decision \\
\hline Male students from broken homes & 49 & 3.90 & 6.22 & 96 & 0.74 & 1.66 & $\begin{array}{l}\text { Not } \\
\text { Significant }\end{array}$ \\
\hline Female Students from broken homes & 49 & 3.53 & 5.75 & & & & \\
\hline
\end{tabular}


$\mathrm{P} \leq 0.05$

From table 3 it is clear that $\mathrm{t}$ - calculated $<\mathrm{p}$-value with $\mathrm{df}=96$ at $\mathrm{P}<0.05$.Thus the null hypothesis is not rejected. In other words, there is no significant difference between male and female students from broken homes.

\section{DISCUSSIONS}

This study aimed at finding out the impact of broken homes on Mathematics academic achievement in senior secondary schools in Nasarawa Zonal Education Office in Kano State. In this study, the value of family circle as a source of love was highlighted. The role family plays in the total development of the child is very important. Salami (2008) argued that home "is the best institution in the world".

One of the findings of this study showed that there is no significant difference in mathematics students' academic performance between those from stable homes and those from broken homes. This finding agrees with those of Ayodele(2006), Alika and Edosa(2012) and Omoruyi(2014).

This study also showed that there was a significant difference in the mathematics performance of students from high income broken homes and those from low income homes. This is in line with the findings of Alika and Edosa \{2012\} and Omoruyi $\{2014\}$ who believed that there is a significant difference between parental socio-economic status and performance.

The third finding of this study showed that there was significant difference between male and female students from broken homes. This is against the finding likes of Sterling $\{1995\}$ as reported in Alika and Edosa $\{2012\}$

\section{CONCLUSION}

The following conclusion can be drawn based on the findings of those students: the students from intact home performed better academically than those from broken home. This implies that some students from broken home have negative impact academically and do not perform well when compared with their counter parts from intact homes due to the social, economic and psychological status of their homes.

Also, the research observed significant difference in the academic achievement of mathematics students from broken and stable home. It also showed that both male and female students from broken homes are academically backward due to their homes status in terms of chorological and mental development.

\section{RECOMMENDATIONS}

General recommendation:-from the study the following are the recommendations made;

1. Parents should endeavor to create peaceful co-existence and enabling environment that could enhance stable family.

2. Students should continue to improve on their academics not minding the circumstances around them.

3. Family should try as much as possible to avoid broken homes. Children from such broken institution suffer.

4. Teaching of family ethics should also be encouraged in the school curriculum.

5. Guidance and counseling service should be provided to the students in order to expose them to some critical issues of life and the ways out.

\section{RECOMMENDATIONS FOR FURTHER STUDY;}


1. There is the need to conduct similar research in other local government areas in the state.

2. There is also another need to conduct a research on the impact of broken homes on mathematics students' social life in any of the local government areas in the state.

3. Another very important research subject is the influence of broken home on children's academic performance in school on which a research should be conducted.

\section{REFERENCES}

Alika,H.I. \& Edosa,O.S. (2012), Relationship between Broken Homes and Academic Achievement of Secondary School Students in Oredo Local Government Area of Edo State, Nigeria. College student Journal, vol. 42, no. 2, pp 256 - 263.

Ayodele S.O. (2006). Educational Opportunities for Nigerian Learners; How do we fare Thus far? A paper presented at the workshop organized by Network for Gender for Sensitive Educational Management in Africa and the British Consul in Nigeria

Datta, A. (2014). Education and society. Sociology of African Education Macmillan Press Ltd. 173-175

Dorle, K.(2015). Mathematics is a useful tool to simplify science by quantification of Phenomena. Mathematical Journal Press.

Sterling ,F. A. (1995). Myths of gender New York: Basic Books.

Ipaye, T. (2016). Roles and Functions of Counseling in Nigerian Schools. The Nigerian Schools. The Nigerian Journal of guidance and counseling 2(1) $87-106$

Isa, S.G.(2010).Effects of Ethnomathematics In The Teaching And Learning Of Mathematics In Kano State Junior Secondary Schools.Unpublished Ph.D Thesis.Bayero University,Kano.

Maiwada \& Yakasai, D.A.M.I (2015). Essentials of educational research and proposal Writing. Zaria: Ahmadu Bello University Press.

Muller, P.A., Stage, F.k., \& Kinzie. J. (2001). Science achievement growth trajectories: Understanding factors related to gender and racial - ethnic difference in Precollege science achievement. American Education Research Journal. 38, 98-1012

Ogunshola, F. \& Adewale, A.M (2012). The effects of parental socio - economic status On Academic performance of students in selected schools in Edu Iga of Kwara State Nigeria.

Omoruyi, I.V. (2014). Influence of Broken homes on Academic performance and Personality development of the Adolescents $\mathrm{n}$ Lagos state metropolis. European Journal of Educational and Development Psychology vol. 2, No. 2, PP. 10-23.

Rothestein, R. (2004). Class and schools using social economic and educational Reforms to close the white and black achievement gap. Economic policy Institute, U.S.A.

Salami, S.O \& Alawode, E.A (2008) on the important of home to the academic Achievement and educational productivity: ^hierarchical linear model.

Young ,D.J.,Reynold,A.J.\&Walberg,H.J.(1996).Science achievement and educational productivity:A hierarchical linear model. Journal of Educational Research, 86(5), 272-278

WWW.scirj.org 
Zubairu, A. Abdullahi, A.H, \& Sani, G.S. (2018). Impact of Broken Homes on Mathematics Academic Achievement in Senior Secondary Schools in Nasarawa Local Government, Kano State. Undergraduate project and published. Kano University of Science and Technology, Wudil. 